\title{
「知識管理ソフト小で社内の專門家を探せ
}

大きな集団や大企業になると、誰が何を知っているのかを調べるのは大変な作業だ。

科学者は情報を共有し、研究が重複しないようにするには、どうすればよいのか。

知識管理(ナレッジマネジメント)ソフトウエアという手法について、Philip Ballが報告する。

原文：Information technology: In the know

NatureVol.428(462-463)/1 April 2004; www.naturejpn.com/digest

Xン 学者の生活では、こんな問題によくイ
ライラさせられる。自分にはちょつと わからないが、詳しい人ならすぐにわかりそ うだ。だが誰に聞けばよいのかわからない。例 えば、基本的な実験手順なら、同じ会社の誰 か、あるいは同じビルにいる人がよく知って いることかもしれない。その人に聞けばすぐ にわかり、数週間分の仕事をせずにすむだろ う。だが、どうやって詳しい人を見つければ よいのだろうか。

専門的な小さいグループに所属する研究者 であれば、周囲の人に聞いて回ればすむ。し かし、世界中に数干人の従業員を抱えている 製薬会社の研究者の場合はどうだろう。ある いは、複数の研究機関にまたがる共同研究を 行う科学者であればどうなるか。同僚一人ひ とりに尋ねて回るのはあまりにも時間がかか りすぎる。電子メールをいっせいに送りつけ るのは、膨大な数の人をイライラさせること になるだろう。

そこで、知識管理システムが解決策となる かもしれない。このソフトウエアは、ある組 織の中で誰が何を知っているかという見取り 図を作成し、その情報をもとに質問と回答を 結びつける。知識管理システムは何度か出だ しでつまずいたものの、製薬業界で一定の成 功を収めた。さらに、現在の科学者の生活に 欠かせない電子ネットワークのおかげで、知 識管理システムはいくつかの新しい方法で実 現し、科学者たちのインフラとなっている。 「従業員 25 人の企業に、知識管理システム は必要だろうか」。ヒューレット・パッカード 社(米国カリフォルニア州パロアルト)の研究 所に所属する情報科学者 Eytan Adar は言う。 「たぶん必要ないだろう。しかし、大西洋の両 側に研究者がいる社員 1 万人の製薬会社の場 合はどうだろう。重複した実験を避けるため に、実験室での作業を常にチェックし続ける

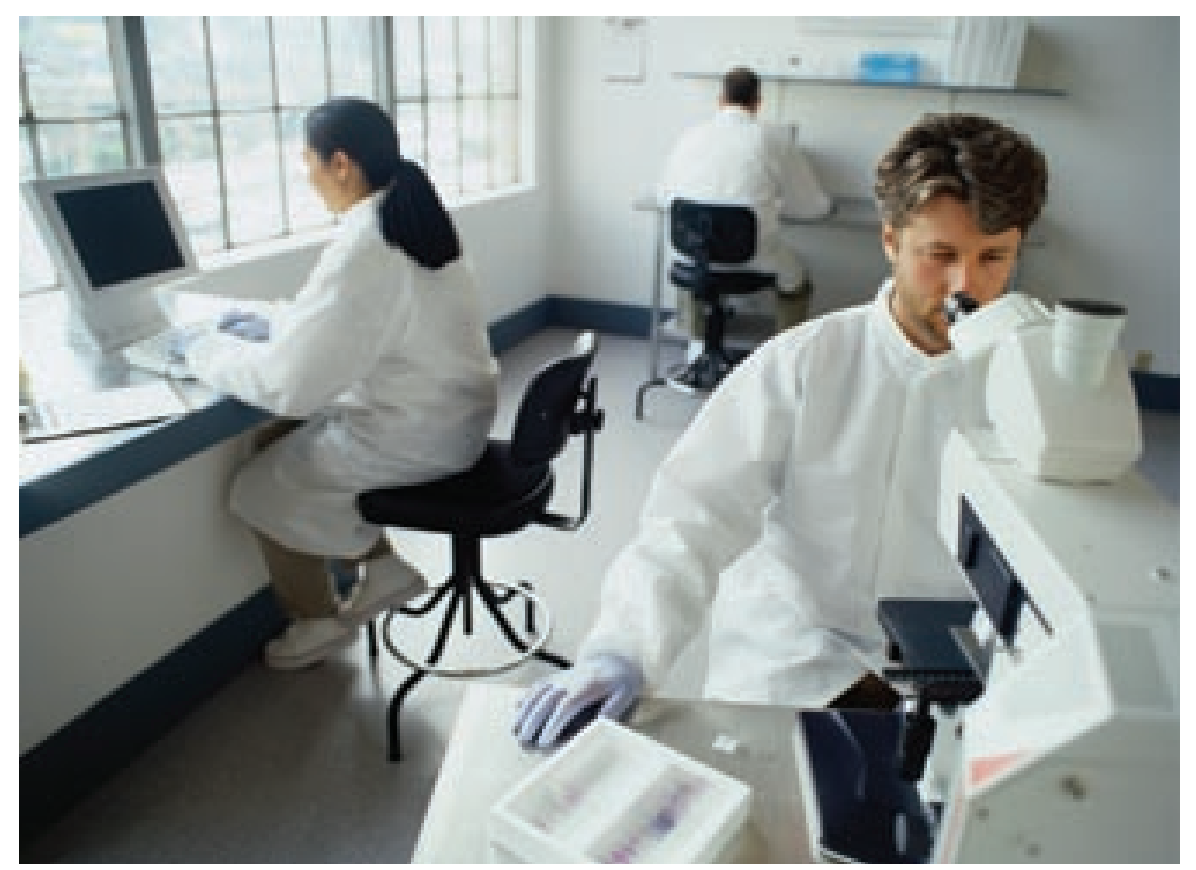

誰かががあなたの問題の解決法を知っているはず。どうやってその人を見つけますか。

ことを選ぶだろうか。その答えは明らかだ」 知識管理システムは、組織の記憶装置であ る。組織の一員が解決したあらゆる問題は、 薬の候補分子のテストから、コンピューター ソフトウエアの問題点の修正にいたるまで、 この記憶装置に蓄えられる。この知識の宝庫 がだれでも利用できるようになっていれば、 問題を解決するのは一度だけですむ。

論文誌の編集者はその経験が長いほど、論 文審査員を選ぶ際に経験を頼りにしている。 2 人の研究者の仲が悪ければお互いの論文を 査読すべきでないことを、ある編集者なら知 っている、というケースもあるだろう。だが、 ほかの編集者はどうやってその情報を得れば よいのか。また、その編集者がいなくなった ら、その知識をいったいどうやって引き継げ ばよしのか。

すべての記録を保存することは現実的では
ないし、有用な情報が大量の雑情報の中に埋 もれてしまうだろう。決定的に重要なヒント となるのは、コ一ヒ一自動販売機のところで 同僚から偶然にもらう意見であることが多か ったりする。本当に重要な情報を伝えている のは、経営者の命令ではなく、仲間のコミュ ニケーションだ。

\section{FAQ のデータベースを構築}

組織の電子的な記憶装置を作ろうとする最 初の試みは、電子データを蓄え、それを分析 して利用する、というものだった。その後に もっとも影響を及ぼした装置のひとつは、ミ シガン大学アナーバー校 (米国ミシガン州ア ナーバー)のコンピュータ科学者 Mark Ackermanが1990年代後半に開発した「アン サーガーデン」(Answer Garden)だ。

これは専門家発見システムというべきもの|》 
で、従業員の専門知識のデータベースを使つ て、ある質問に答えるのに適した人を見つけ 出す。データベースは従業員の自発的な申告 にもとづいて作られた。システムのユーザー には、よく出る質問とその答え $(F A Q)$ が提 供される。これだけで、別の従業員に助言を 求める必要がなくなることもあるかもしれ ない。FAQ で要求を満たせないときは、ユ一 ザーは電子メールで専門家にコンタクトする ことができ、得られた答えはFAQに加えられ る。

ユーザーに合った專門家を見つけるという 仕組みにもとづいたシステムはほかにもあ り、ほぼ同時期に現れた。だが、その期待は裏 切られた。食品·化学品メ一カ一、ユニリーバ の英国イングランド北部のポートサンライト にある研究所に所属する知識管理の専門家 Simon Mastertonは、この問題について2000 年に発表した論文の中で触れている。彼は、現 在口バートゴードン大学(英国・アバディー ン)に所属する同僚のStuart Wattとの共著論 文の中で、次のように書いた。「新しい知識管 理システムには、最初はよい反応があること がほとんどだ。多くの人は数回、システムを 試験的に使ってみるだろう。しかし残念なが ら、ほとんどはすぐに使われなくなってしま う」

学術研究を行っているグループやコンピュ ー夕企業が「アンサーガーデン」という知識管 理システムを実地に試したときにAckerman が経験したことも、これとまったく同じだっ だ。あるユーザーは「理屈の上ではすごくよ しものに思えた。だが、詳細な情報に到達し てみると、労多くして功少なしといった感じ

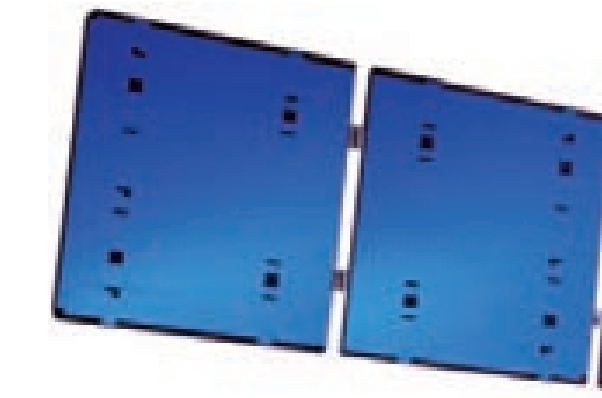

チャンドラX線観測衛星の研究チー ムは知識管理に対する初期の熱意を 失ってしまった。
だ。実際のところ、それを使うほどの時間の 余裕がない」と言う。

さらに微妙な問題もあった。有用な知識と いうものは、状況から切り離して蓄えること ができるとは限らないと、ユーザーたちは感 じた。また、知識を共有することを好まない 人もいた。アンサーガーデンは知識を共有す るための時間と労力がかかりすぎて、ずつと 使い続けたいと思わせるものではなかった。

科学の世界での知識管理システムも、最初 のビジネス用知識管理システムが現れたこ ろに一時的に流行した。1990 年代の初め、 八一バード・スミンニアン宇宙物理学セン ター(米国マサチューセッツ州ケンブリッジ) のEric Mandel は、Ackerman とともにASSIST と呼ばれる天文学者のための知識管理 システムを開発した 5 。天文学者は多種類の データを、互換性のない多種類のソフトウエ アパッケージで解析することが多い。ASSIST は、そのようなソフトウエアを単一の電子環 境の中に納め、ユーザーが情報や説明を書き 込んで更新できるようになっていた。これを 「生き字引」と呼ぶユーザーもいた。

\section{製薬会社で威力を発揮する}

ASSIST は 1992 年に公開され、最初の4 力月 間で40を超える天文学研究機関が利用し、コ ンプトンガンマ線観測衛星や AXAF (先端X線 宇宙物理学装置、現在はチャンドラX線観測 衛星と呼ばれる)などの米航空宇宙局(NASA) の計画で使われた。それにもかかわらず、 ASSIST は受け入れられなかった。Mandelに よると、ASSISTはうまく稼動したが、後ろ楯 が得られなかったという。「ASSISTを本格的 に使えるような、天文学上の大規模プロジェ

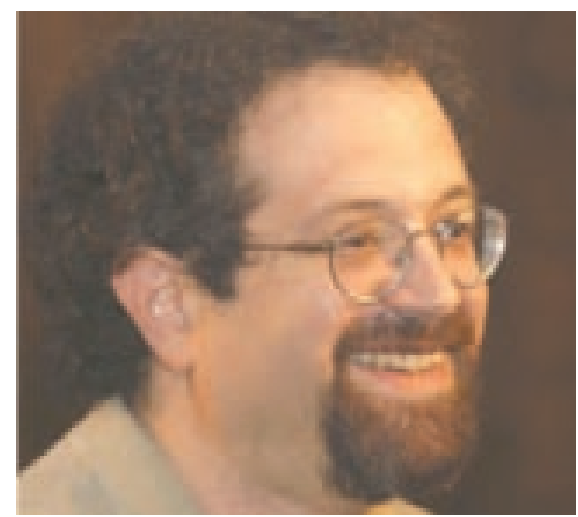

Mark Ackerman は研究者の専門知識の共有に役 立つプログラムを開発した。

クトがどうしても必要だったと思う。そうす ればASSISTの本当に革新的な能力が実証さ れたかもしれない。だが、そのようなプロジ エクトを勝ち取ることはできなかった」と Mandelは話す。「NASAの計画では、ASSIST は限定的にしか使用されず、ASSISTを試して みるのに必要なチュートリアルを進んで作る 者もいなかつた」と Mandel はつけ加えた。

それでも、科学の世界で知識管理が途絶え てしまったわけではない。以前のシステムと は見た目には異なるが、実際には科学の世界 で知識管理は広く行われている、とAckerman は言う。コーネル大学(米国二ューヨーク州 イサカ)が運営する物理学プレプリントサー バー「arXiv」は、同じ専門分野の研究者同士の 知識共有システムのシンプルな実例だとい う。「科学者たちは、知識管理技術の先端ユ一 ザーであるだけではなく、ビジネスでの利用 にも応用できる新技術も作り出している」と Ackerman は話す。

新しいタイプの知識管理ソフトウエア も、ここ数年に登場している。製薬会社ア

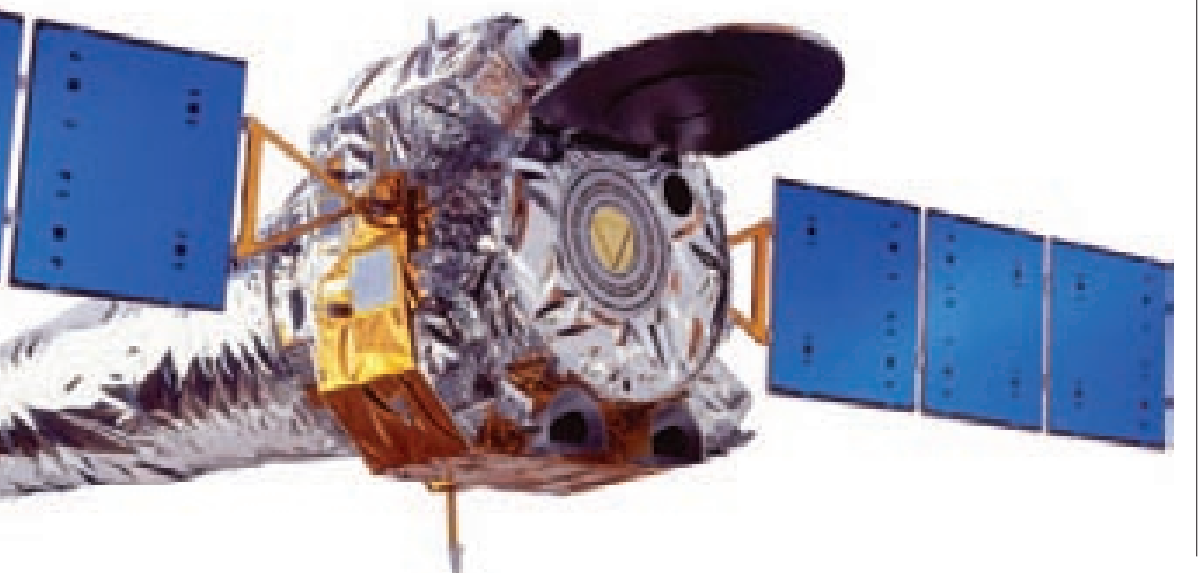


ベンティスの従業員は、「ナレッジメール」 (KnowledgeMail) と呼ばれる新しいシステ ムを使っている。2001年のことだった。ドイ ツのフランクフルトにあるアベンティスの 血栓症·变形性関節炎疾患領域研究部門の研 究者が、自分の研究していたマクロファージ (白血球の一種)をどうやって培養し、選別す るかという問題を解決しなければならなかっ た。この研究者は、その情報はすでに存在す るはずだと思ったが、それを見つけ出すには 数週間かかるとわかっていた。

アベンティスには約 5,000 人の研究スタッ フと 7 万 5,000 人の従業員がいる。アベンティ スの誰かがすでにこの問題を解決している可 能性は十分あった。ナレッジメールはすぐに、 アベンティスの米国マサチューセッツ州ブリ ッジウォーターにある部門の 2 人の研究者を 探し出し、この 2 人は必要な情報を提供する ことができた。

\section{メールをスキャンして專門性を判断}

ナレッジメールは、カリフォルニア州パロア ルトにあるタシット・ナレッジ・システムズ社 が作った。このソフトウエアは、電子メールか ら得られた単語とフレーズにもとづいてユー ザーの専門知識のプロフィールを作る。大ざっ ぱに言えば、ある研究者がマクロファージに 関する電子メールを多数受け取れば、この研 究者はマクロファージの専門家であるとソフ トウエアは判断し、この研究者に合った質問 を送る。これで、ユーザーはほとんど何もしな くても專門家プロフィールが出来上がる。夕 シット社のソフトウエアは、製薬会社アスト ラゼネカや軍需·航空宇宙機器メーカ一、ロッ キード・マーチンでも使われた。現在、ナレッ ジメールは「アクティブネット」(ActiveNet) という製品へと発展している。

アベンティスは 2001 年に行った 3 力月間 の試用で、ナレッジメールのおかげで7.8人月 の労働力が節約できたと見積もった。ドイツ、 フランス、米国の 435 人の試用ユーザーのう ち、80\% を超えるユーザーがこのソフトの使 用継続を求めた。アベンティスは現在、この システムの使用を延長している。ほかの製薬 会社も同様のソフトウエアパッケージを検討 中だ。

しかし、ナレッジメールのようなシステム に問題がないわけではない。「詳細なプロフィ NATURE月刊ダイジェスト|5 月号
一ルを作る場合、ユーザーのプライバシーが 保たれるという保証が必要になる」とAdarは 話す。ユーザーが自分のプロフィールにアク セスできるようすれば、そのような不安を解 消する一法になるかもしれない。

Adar らは、「ソーシャル・八ーベスティン グ・オブ・コミュニティ・ナレッジ」(Social Harvesting of Community Knowledge) $と$ いうソフトウエアを設計しだ。これは、ユー ザーの電子メールの自動検索、訪れたウエブ ページ、表示した文書などの情報を使って、 専門知識プロフィールを作り上げるソフトウ エアだ。ユーザーは自分自身で申告したプロ フィールに興味と技能を列挙することもで き、自身のプロフィールを書き換えることも できるし、ある情報源をプロフィール自動作 成のデータとしないことも選択できる。テス トユーザーにはこうした手段は貴重だった。 これによって客観的なプロフィールを維持で きなくなるかもしれないが一一自分自身に対 して抱いているイメージというものは、現実 からかけ離れていることが多いからだ。

Adarが作ったようなシステムがこうした 問題を解決できれば、新しいタイプの知識管 理ソフトウエアは、初期のソフトウエアがつ まずいた障壁を乗り越えられるかもしれな い。研究現場によっては、そうしたシステム があれば、うんざりするような文献検索の手 間が減る可能性がある。

知識管理システムがユーザーのプライバ シーを侵害することなく、また、ユーザーに あまりにも多大な時間的負担をかけずに、そ うした利便性を実現できれば、私たちにとつ て不可欠なコンピュータープログラムのひと つとなるかもしれない。

\section{Philip Ballはネイチャーの編集顧問。}

1. Ackerman, M. S. ACM Trans. Inf. Syst. 16, 203-224 (1998).

2. Masterton, S. \& Watt, S. Inf. Syst. Front. 2, 299-315 (2000).

3. Ackerman, M. S. Inf. Technol. People 9, 10-24 (1996).

4. Ackerman, M. S. \& Halverson, C. in Social Capital and Information Technology (eds Wulf,V. \& Huysman, M.) (MIT Press, Cambridge MA, 2003).

5. Ackerman, M. S. \& Mandel, E. J. Organ. Comput. Electr. Comm. 9, 105-127 (1999).

6. Adar, E., Lukose, R., Sengupta, C., Tyler, J. \& Good, N. Inf. Syst. Front. 5, 15-28 (2003).

KnowledgeMail

www.mindsharesolutions.co.uk/products

Social Harvesting of Community Knowledge

www.hpl.hp.com/research/idl/projects/shock

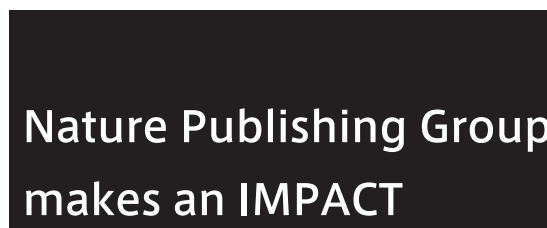

\section{makes an IMPACT}

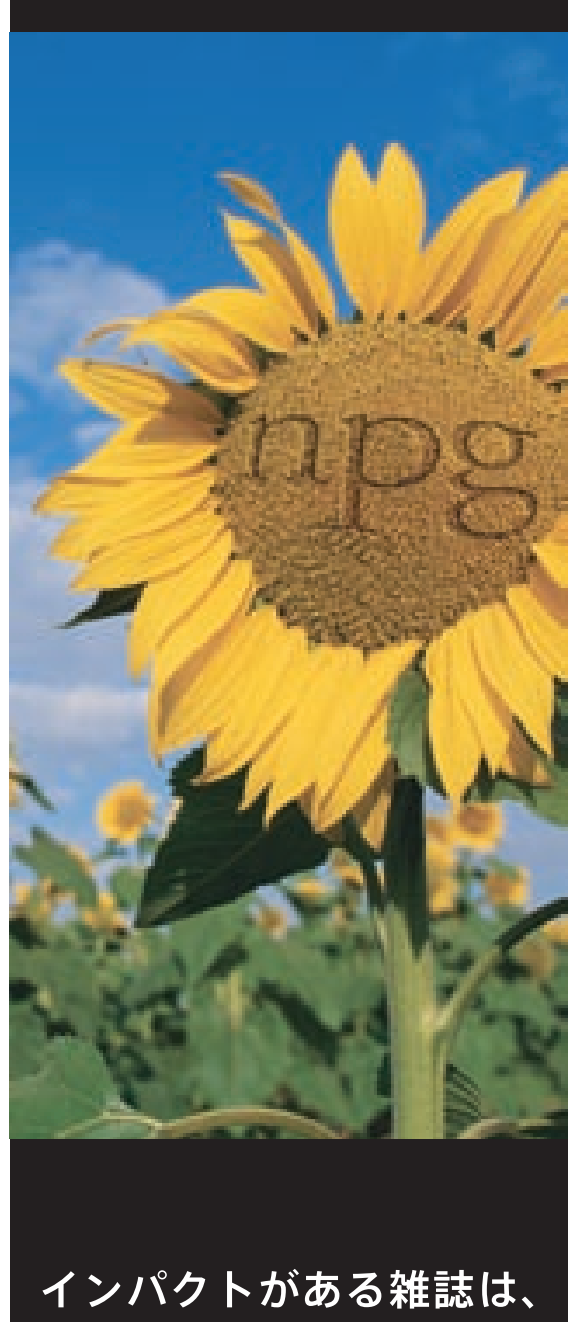

Nature です。
2002年度、Nature のインパクト

ファクターは30.432でした。

もちろんmulti-disciplinaryジャーナル

のナンバー1です。 